\title{
Isolation of Multi-Resistant Bacteria of Patients Suffering from Urinary Tract Infections in Owerri Metropolis, Imo State, Nigeria
}

\section{Umeaku Chinyelu Nkiru ${ }^{1 *}$, Chimezie Christian Chukwudi ${ }^{1}$, Ozoh Chinwendu Njideka ${ }^{2}$, Nwajiobi Favour Okwukweka ${ }^{2}$, Abana Chioma Chineze $^{2}$ and Umeaku-Uzor Ugonwa Chiagoziem ${ }^{3}$}

${ }^{1}$ Department of Microbiology, Chukwuemeka Odumegwu Ojukwu University, Uli Campus, Nigeria

${ }^{2}$ Department of Applied Microbiology and Brewing, Nnamdi Azikiwe University, Nigeria

${ }^{3}$ Department of Mass Communications, Chukwuemeka Odumegwu Ojukwu

University, Igbariam Campus, Nigeria

*Corresponding Author: Umeaku Chinyelu Nkiru, Department of Microbiology, Chukwuemeka Odumegwu Ojukwu University, Uli Campus, Nigeria.
Received: July 03, 2021

Published: August 05, 2021

(C) All rights are reserved by Umeaku

Chinyelu Nkiru., et al.

\section{Abstract}

The isolation and genetic analysis of multi-resistant bacteria of patients suffering from urinary tract infections in Owerri metropolis of Imo State, Nigeria was evaluated. A total of 50 urine samples were collected from Federal Medical Centre, Owerri. Streak plate method of cultivation of microorganisms was adopted in the different selective media used; MacConkey, Salmonella shigella, mannitol salt and eosin methylene blue agars. Nutrient agar was used for the sensitivity. Out of the 50 samples, 9 were male and 41 were females. The patients aged between 20 and 40 years. Results revealed the following organisms; Escherichia coli, Staphylococcus aureus, Salmonella spp., Klebsiella spp., and Pseudomonas aeruginosa. E. coli had the highest occurrence of 56\%, followed by S. aureus with 26\%, Salmonella with 8\%, while Klebsiella and Pseudomonas aeruginosa had $6 \%$ and $4 \%$ respectively. The isolates were resistant to most of the antibioitics used. Sp (Sparfloxacin) showed the highest zone of inhibition with a diameter of $23 \mathrm{~mm}$, and the lowest is $1.0 \mathrm{~mm}$ (CN:Gentamycin). E. coli was mostly resistant to SXT (Septrin), CH (Chloramphenical), CN (Gentamycin), S (Streptomycin), and GPX (Tarivid). Klebsiella was resistant to SXT (Septrin), CH (Chloramphenical), CN (Gentamycin), S (Streptomycin), and GPX (Tarivid). Pseudomonas was resistant to SXT (Septrin), CH (Chloramphenicol) and S. aureus was only resistant to SXT (Septrin), AM (Amoxacillin), and R (Rocephine). The organisms show high resistance to SXT (Septrin), CH (Chloramphenical), CN (Gentamycin), GPX (Tarivid), and S (Streptomycin). Plasmid extraction and Agarose gel electrophoresis was done to determine the presence of 16SrRNA gene, CTX-M gene, BlaTEM gene, SHV gene and OX gene on Escherichia coli and Salmonella spp and the result shows 1500bp of $16 \mathrm{~s}$ gene at $100 \mathrm{bp}$ molecular ladder for $16 \mathrm{SrRNA}$ gene, $550 \mathrm{bp}$ gene bands of CTX-M at $100 \mathrm{bp}$ molecular ladder of $1500 \mathrm{bp}$, $401 \mathrm{bp}$ of Bla TEM gene bands at 100bp molecular ladder of $1500 \mathrm{bp}$ and $293 \mathrm{bp}$ of SHV gene bands at 100pb molecular ladder of $1500 \mathrm{bp}$, with OX gene showing no band. The bacteria studied contain antibiotic resistant genes. Therefore, indiscriminate use of antibiotics should be avoided.

Keywords: Escherichia coli; Salmonella; Isolation; Owerri Metropolis 


\section{Introduction}

Antimicrobial resistance has been identified as one of the greatest threats to human health and developing countries like Nigeria are worst hit by this crisis [1]. The major cause of this crisis is the indiscriminate and widespread use of antibiotics, especially the antibiotics containing beta-lactam ring for example; Cefozopran, Cefquinome etc, in prophylaxis and treatment of bacterial diseases.

Antimicrobial resistance (AMR) has become a significant threat to the prevention and treatment of bacterial infections globally [2]. Importantly, in low- and middle-income countries, the potential for AMR to lead to increased morbidity and mortality may be greater given the higher burden of bacterial illness in low-income countries, delayed presentation, weaker access to diagnostics (particularly in Microbiology) and the reduced availability of second-line antibiotics [3].

Urinary tract infections (UTIs) are a community-acquired infection that represent a major burden for most healthcare systems, partially due to ineffective or inappropriate antibiotic treatment leading to treatment failures [4].

Urinary tract infection (UTI) is caused by the presence and growth of microorganisms within the urinary tract system [5]. Urinary tract infections are among the most common bacterial infections in humans both in the community and hospital settings, and they occur in all age groups, and usually required urgent treatment. In West Africa region, particularly in patients with UTI, a high level of AMR has been reported and it raises particular concerns over proper diagnosis and treatment with appropriate antibiotics thereafter. Urinary tract pathogens in Nigeria are associated with a moderate to high level of resistance to commonly used antibiotics such as Cefepime, Cefoxitin, Ciprofloxacin, Gentamycin etc. Studies from West Africa revealed moderate to high rates of AMR among Escherichia coli and Klebsiella spp. to ampicillin, Amoxicillin-clavulanic acid and septrin both among inpatients and outpatients [2]. In addition, AMR was unexpectedly observed among inpatients with UTIs to third generation cephalosporins, suggesting that extendedspectrum $\beta$-lactamase (ESBL)-producing organisms may be important pathogens in this clinical context [2]. The common etiologic agents of UTI include Enterobacteriacae like Escherichia coli and Klebsiella spp, as well as Gram positive organisms like Staphylococci and Enterococci as well as Candida albicans in patients with under- lying physiological debilitation [6]. Escherichia coli accounts for up to $80 \%$ of community-acquired uncomplicated UTIs because of its gene level mutation [7].

UTI is commonly treated with oral antibiotics like amoxicillinclavulante, nitrofurantoin, cephalosporins, fluoroquinolones and trimethoprim-sulfamethoxazole [6]. However, available data indicate that Nigeria has isolates with high levels of resistance to Cephalosporins [8], thus underscoring the need for regular institutional, regional and national surveillance in order to optimize care. The antimicrobial resistance patterns of bacterial isolates from urinary tracts differ among bacterial and antibiotics, geographic regions and institutions [9]. There is a growing concern regarding antimicrobial resistance worldwide involving gram negative bacteria such as E. coli, Klebsiella spp and Proteus mirabilis, all known to be the dominant causative agents of UTIs compared to the gram positive such as Stapylococci and Enterococci [7].

This study will provide useful laboratory data to monitor the status of antimicrobial resistance of some uropathogens, to improve physicians' prescribing habits, treatment recommendations and encourage the national regulatory agency in checkmating antibiotic abuse within the region.

\section{Statement of problem}

According to a report by [1], African region has one of the largest gaps in data on the prevalence of AMR resulting from limited laboratory capacity and surveillance networks. An external quality assessment reported several deficits in antimicrobial susceptibility testing in many African countries [2].

The spread of these resistant bacteria isolates including the ESBLs has posed a threat to health with respect to hindering effective treatment, prolonged hospitalization and increased treatment costs [6]. The level at which patients suffer UTI is alarming and hence the need to do more research if needed considering the damages that it can cause. The main danger associated with untreated UTI is that the infection may spread from the bladder to one or both kidneys. When bacteria attack the kidneys, they can cause damage that will permanently reduce kidney function. It can also lead to infertility.

However, Urinary pathogens especially from community patients have been known to include strains that are resistant to 
many of the commonly used antibiotics. Therefore, there is need for periodic monitoring of etiologic agents of urinary tract infections, and their susceptibility pattern especially in rural settings. Against this background, as well as the paucity of reports of multidrug resistance in urinary tract infections in Owerri metropolis, this study was undertaken.

\section{Significance of study}

The rise of drug-resistant infections is worrisome. In many of these resistant urinary tract infections, it may simply be impossible to identify properly the causative agents and which patients are at risk due to poor microbiological diagnosis. These have necessitated the need for extensive research on antibiotic resistance among the patients who are on antibiotic therapy due to UTI so as to increase awareness campaign on antimicrobial resistance among etiological agents most especially in developing countries like Nigeria, where there is no or less surveillance activities and regulations guiding the use of antibiotics.

The results from this study will possibly proffer practical solutions to curtai the spread of these organisms in hospitals or communities by highlighting the best practices, infection control measures and appropriate choices of empirical antimicrobial coverage for infections due to resistant strains.

\section{Justification}

There are few data regarding etiologic agents of UTIs and their respective antibiotic sensitivity in our country, through the findings of this study, we intend to update the limited knowledge or information about common etiologic agents and respective antibiotic sensitivity which is crucial for stakeholders to search for preventive and control measures against antibiotic resistance.

\section{Aim of the Study}

The aim of this study is to investigate the prevalence of MultiDrug resistant bacteria in patients with Urinary Tract Infection (UTI) in Owerri, South Eastern Nigeria.

The specific objectives of this study are:

- To isolate and identify bacteria associated with urinary tract infections.

- To identify the risk factors exposing patients to these resistant strains
- To determine the antibiogram of the bacteria isolates.

- To determine the multiple antibiotic resistance index (MARI).

- Genetically identify the isolates.

- To determine the molecular drug resistant markers among the resistant strains.

\section{Materials and Methods}

Study area

This study was conducted at Federal Medical Center Owerri, Imo State.

\section{Ethical clearance}

The ethical clearance for this study was obtained from Federal Medical Centre, Owerri, Imo State.

\section{Sample and data collection}

A total of 50 clinical urine samples were collected from patients who visited the Federal Medical Center Owerri (FMC) for medical care and were referred to Medical Microbiology and Parasitology Laboratories for laboratory investigations relating to Urinary tract infections. These patients did not include those who were on any antibiotic one week before the samples were collected. The urine samples were collected using labeled $20 \mathrm{ml}$ calibrated sterile universal containers from both inpatients and/or outpatients. The criteria for selection were based on patients seen either at the GOPD or those on admission with clinical symptoms suggestive of urinary tract infection.

The patients were instructed on how to collect clean catch midstream urine samples (MSU) of about (10-15 ml) in a sterile disposable container.

Demographic data and other relevant information from the patients that were recruited for this study were collected from the folder of patients.

\section{Isolation and identification of bacteria}

A loopful $(0.001 \mathrm{~mL})$ of well mixed un-centrifuged urine was streaked on to the surface of $5 \%$ blood agar and cysteine lactose electrolyte deficient (CLED) medium. The plates will be incubated aerobically at $37^{\circ} \mathrm{C}$ for $24 \mathrm{hrs}$. Cultures without any colony at the end of $24 \mathrm{hrs}$ incubation will be further incubated for $48 \mathrm{hrs}$. Colony 
counts of $\geq 10^{5} \mathrm{cfu} / \mathrm{ml}$ in the culture will be considered positive for UTI as suggested by [5].

Colonies from culture plates of individual patients were subcultured onto nutrient agar plates and incubated at $37^{\circ} \mathrm{C}$ to obtain pure culture characteristics. After $24 \mathrm{hrs}$, pure colonies were transferred into agar slants and incubated further for $24 \mathrm{hrs}$. After incubation at the appropriate temperature as stated above, the agar slants were stored in the refrigerator under $4^{\circ} \mathrm{C}$ until further use.

Culture plates of pure colonies of the isolates were examined for colonial appearances such as colony color, odor, consistency, opacity, size, elevation and edges and of colonies. The colonies were identified and confirmed using standard microbiological methods which include Gram staining, colonial morphology on media, and growth on selective media, lactose and mannitol fermentation.

\section{Grams staining}

The isolated bacteria were stained using Grams staining technique to differentiate between gram positive bacteria and Gramnegative bacteria. The techniques that were employed during staining process followed thus:

- From pure culture of bacteria from an individual, a smear of a bacterial colony was made on a grease free slide

- The slides were allowed to air dry and heat-fixed over a Bunsen burner

- Crystal violet stain was used to flood the slide for $1 \mathrm{~min}$., and afterwards rinsed with distilled water

- Gram's iodine, a mordant was used to flood the slide for $1 \mathrm{~min}$., and afterwards rinsed with distilled water

- $75 \%$ alcohol was applied onto the stained slides for $10 \mathrm{sec}$, and rinsed with distilled water

- Safranin, a counter stain was used to flood the slide for $1 \mathrm{~min}$., and afterwards rinsed with distilled water.

- The stained slides were air-dried and viewed under the microscope using x 100 lens with immersion oil. The stain character and shape of the bacterial shape will be recorded.

\section{Biochemical tests}

The staining was followed by biochemical tests and culturing in selective and differential medium for suspected organisms.
Eosin methylene blue (EMB) agar

EMB agar is a differential plating medium for the detection and isolation of the Gram-negative enteric bacteria. It aids in the differentiation of lactose fermenting bacteria from non-lactose fermenting bacteria. It is used in the differentiation of Enterobacteracea genes and Escherichia coli.

\section{Test procedures}

Appropriate quantity of EMB agar was dissolved in required volume of the agar according to manufacturer's instructions. It was sterilized at $121^{\circ} \mathrm{C}$ for $15 \mathrm{mins}$ after which it was aseptically poured into sterile petri dishes and allowed to gel. Test organism was directly inoculated onto the surface of an EMB agar plate. It was incubated aerobically at $37^{\circ} \mathrm{C}$. Observation for specific cultural characteristics and color changes was made after 18 - 24 hours of incubation.

\section{Interpretations}

- Coliforms that utilize the lactose and/or sucrose are blue/ black with a greenish metallic sheen indicated Escherichia coli.

- Coliforms such as Klebsiella pneumonia have mucoid colonies that may be purple and/or exhibit a green metallic sheen.

- Good to excellent, colorless colonies indicated of Proteus vulgaris, Salmonella and Shigella spp.

\section{Antibiotics susceptibility test}

The antibiotics susceptibility procedure for bacterial isolates was carried out using Kirby-Bauer method. This method depends on the ability of disc to permit the penetration of antibiotics through the medium. $0.1 \mathrm{ml}$ McFarland turbidity standard of test cultures was inoculated unto a sterile solidified Mueller Hinton agar. Commercially available antibiotics sensitivity disc was aseptically placed on the surface of the medium. This was incubated at $37^{\circ} \mathrm{C}$ for $24 \mathrm{hrs}$. The diameter of inhibition was recorded and inferences (Susceptibility criteria) were made based on Clinical and Laboratory Standard Institute [10].

\section{Antibiotics to be used}

A total of 16 antibiotics for both Gram positive and Gram negative bacteria were used in this study and they include: Amikacin (AK) $30 \mu \mathrm{g}$, Aztreonam (ATM) $30 \mu \mathrm{g}$, Cefepime (FEP) $30 \mu \mathrm{g}$, Cefo- 
taxime (CTX) $30 \mu \mathrm{g}$, Cefoxitin (FOX) $30 \mu \mathrm{g}$, Ceftazidime (CAZ) $30 \mu \mathrm{g}$, Ceftriaxone (CRO) $30 \mu \mathrm{g}$, Chloramphenicol (C) $30 \mu \mathrm{g}$, Ciprofloxacin (CIP) $5 \mu \mathrm{g}$, Colistin Sulphate (CT) $25 \mu \mathrm{g}$, Gentamicin (CN) $30 \mu \mathrm{g}$, Kanamycin (K) $5 \mu \mathrm{g}$, Meropenem (MEM) $10 \mu \mathrm{g}$, Nitrofurantoin (F) 300 $\mu \mathrm{g}$, Tetracycline (TE) $25 \mu \mathrm{g}$ and Sulfamethoxazole/Trimethoprim (SXT) $30 \mu \mathrm{g}$.

\section{Multiple antibiotics resistance index (MARI)}

The multiple antibiotics resistance index was calculated as the ratio of number of antibiotics to which the isolates were resistant/ the total number of antibiotics against which the isolates were tested (a/b). MAR index values that are greater than 0.2 (20\%) were considered to be high due to often use of antibiotic as described by [11].

\section{Molecular study on multidrug resistance}

Resistant bacterial isolates were selected to test for the presence or absence of resistant genes such as quinolone resistant genes (qnr genes) and carbapenem resistant gene (blaKPC). Plasmids were isolated from the resistant bacterial isolates using the manual of extraction kit (ZymoMiniprep Kit) and resolved by electrophoresis in $1 \%$ agarose gel with ethidium bromide.

The presence or absence of resistant genes (blaKPC, qnrA, qnrB and qnrS) were carried out by PCR reaction as previously described by Elsayed and his colleagues [12].

The reaction mixture $(20 \mu \mathrm{L})$ contained $1 \mu \mathrm{L}$ DNA tempelete, 2 $\mu \mathrm{L} 10 \mathrm{x}$ buffer, $2 \mu \mathrm{L}$ dNTPs (dGTP, dATP, dCTP and dTTP), $0.2 \mu \mathrm{L}$ Taq DNA polymerase, $1 \mu \mathrm{L}$ of each primer (forward and reverse) and $12.8 \mu \mathrm{L}$ water (nuclease free). The samples were gently vortexed and the PCR was performed using the thermal cycling condition including the annealing temperature for each gene.

\section{Molecular methods of identification}

\section{DNA extraction}

Five milliliters of an overnight broth culture of the bacterial isolate in Luria Bertani (LB) was spun at 14000 rpm for 3 min. The cells were re-suspended in $500 \mu \mathrm{l}$ of normal saline and heated at $95^{\circ} \mathrm{C}$ for $20 \mathrm{~min}$. The heated bacterial suspension was cooled on ice and spun for $3 \mathrm{~min}$ at $14000 \mathrm{rpm}$. The supernatant containing the DNA was transferred to a $1.5 \mathrm{ml}$ micro centrifuge tube and stored at $-20^{\circ} \mathrm{C}$ for other downstream reactions.

\section{DNA quantification}

The extracted genomic DNA was quantified using the Nanodrop 1000 spectrophotometer. The software of the equipment was launched by double clicking on the Nanodrop icon. The equipment was initialized with $2 \mu$ l of sterile distilled water and blanked using normal saline. Two microlitre of the extracted DNA was loaded onto the lower pedestal; the upper pedestal was brought down to contact the extracted DNA on the lower pedestal. The DNA concentration was measured by clicking on the "measure" button.

\section{S rRNA Amplification}

The 16s rRNA region of the rRNA gene of the isolates were amplified using the 27F: 5'-AGAGTTTGATCMTGGCTCAG-3' and 1492R: 5'-CGGTTACCTTGTTACGACTT-3' primers on a ABI 9700 Applied Biosystems thermal cycler at a final volume of 40 microlitres for 35 cycles. The PCR mix included: the X2 Dream taq Master mix supplied by Inqaba, South Africa (taq polymerase, DNTPs, $\mathrm{MgCl}$ ), the primers at a concentration of $0.5 \mu \mathrm{M}$ and the extracted DNA as template. The PCR conditions were as follows: Initial denaturation, $95^{\circ} \mathrm{C}$ for 5 minutes; denaturation, $9^{\circ} \mathrm{C}$ for 30 seconds; annealing, $52^{\circ} \mathrm{C}$ for 30 seconds; extension, $72^{\circ} \mathrm{C}$ for 30 seconds for 35 cycles and final extension, $72^{\circ} \mathrm{C}$ for 5 minutes. The product was resolved on a $1 \%$ agarose gel at $130 \mathrm{~V}$ for 30 minutes and visualized on a blue light transilluminator for a $1500 \mathrm{bp}$ amplicons.

\section{Extended spectrum beta-lactamase detection}

Amplification of SHV genes

SHV genes from the isolates were amplified using the SHV F: 5' CGCCTGTGTATTATCTCCCT-3' and SHV R: 5'-CGAGTAGTCCACCAGATCCT-3' primers on ABI 9700 Applied Biosystems thermal cycler at a final volume of 30 microlitres for 35 cycles. The PCR mix included: the X2 Dream taq Master mix supplied by Inqaba, South Africa (taq polymerase, DNTPs, $\mathrm{MgCl}$ ), the primers at a concentration of $0.4 \mathrm{M}$ and 50ng of the extracted DNA as template. The PCR conditions were as follows: Initial denaturation, 95으 for 5 minutes; denaturation, $95^{\circ} \mathrm{C}$ for 30 seconds; annealing, $56^{\circ} \mathrm{C}$ for 40 seconds; extension, $72^{\circ} \mathrm{C}$ for 50 seconds for 35 cycles and final extention, $72^{\circ} \mathrm{C}$ for 5 minutes. The product was resolved on a $1 \%$ agarose gel at $120 \mathrm{~V}$ for 25 minutes and visualized on a UV transilluminator for a $281 \mathrm{bp}$ product size.

\section{Amplification of TEM genes}

TEM genes from the isolates were amplified using the TEMF: 5'-ATGAGTATTCAACATTTCCGTG-3' and TEMR: 5'-TTACCAATGCT- 
TAATCAGTGAG-3' primers on a ABI 9700 Applied Biosystems thermal cycler at a final volume of 40 microlitres for 35 cycles. The PCR mix included: the X2 Dream Taq Master mix supplied by Inqaba, South Africa (Taq polymerase, DNTPs, $\mathrm{MgCl}$ ), the primers at a concentration of $0.4 \mathrm{M}$ and 50ng of the extracted DNA as template. The PCR conditions were as follows: Initial denaturation, $95^{\circ} \mathrm{C}$ for 5 minutes; denaturation, $95^{\circ} \mathrm{C}$ for 30 seconds; annealing, $55^{\circ} \mathrm{C}$ for 30 seconds; extension, $72^{\circ} \mathrm{C}$ for 30 seconds for 35 cycles and final extension, $72^{\circ} \mathrm{C}$ for 5 minutes. The product was resolved on a $1 \%$ agarose gel at $120 \mathrm{~V}$ for 25 minutes and visualized on a UV transilluminator for a $400 \mathrm{bp}$ product size.

\section{Amplification of OXA genes}

OXA genes from the isolates were amplified using the OXA1F: 5'- AGCCGTTAAAATTAAGCCC-3' and OXA-1R: 5'-CTTGATTGAAGGGTTGGGCG-3' primers on a ABI 9700 Applied Biosystems thermal cycler at a final volume of 40 microlitres for 35 cycles. The PCR mix included: the X2 Dream taq Master mix supplied by Inqaba, South Africa (taq polymerase, DNTPs, $\mathrm{MgCl}$ ), the primers at a concentration of $0.4 \mathrm{M}$ and 50ng of the extracted DNA as template. The PCR conditions were as follows: Initial denaturation, $95^{\circ} \mathrm{C}$ for 5 minutes; denaturation, $95^{\circ} \mathrm{C}$ for 30 seconds; annealing, $47^{\circ} \mathrm{C}$ for 30 seconds; extension, $72^{\circ} \mathrm{C}$ for 40 seconds for 35 cycles and final extension, $72^{\circ} \mathrm{C}$ for 5 minutes. The product was resolved on a $1 \%$ agarose gel at $120 \mathrm{~V}$ for 25 minutes and visualized on a UV transilluminator for a $911 \mathrm{bp}$ product size.

\section{Amplification of CTX-M genes}

CTX-M genes from the isolates were amplified using the CTXMF: 5'-CGCTTTGCGATGTGCAG-3' and CTX-MR: 5'-ACCGCGATATCGTTGGT-3' primers on a ABI 9700 Applied Biosystems thermal cycler at a final volume of 40 microlitres for 35 cycles. The PCR mix included: the X2 Dream taq Master mix supplied by Inqaba, South Africa (taq polymerase, DNTPs, $\mathrm{MgCl}$ ), the primers at a concentration of $0.4 \mathrm{M}$ and 50ng of the extracted DNA as template. The PCR conditions were as follows: Initial denaturation, $95^{\circ} \mathrm{C}$ for 5 minutes; denaturation, $95^{\circ} \mathrm{C}$ for 30 seconds; annealing, $52^{\circ} \mathrm{C}$ for 30 seconds; extension, $72^{\circ} \mathrm{C}$ for 30 seconds for 35 cycles and final extension, $72^{\circ} \mathrm{C}$ for 5 minutes. The product was resolved on a $1 \%$ agarose gel at $120 \mathrm{~V}$ for 25 minutes and visualized on a UV transilluminator for a $550 \mathrm{bp}$ product size.

\section{Results}

After 24 hours of incubation of the urine samples on different selective media, the morphological characteristics of the different isolates were recorded below.

\begin{tabular}{|c|c|c|c|c|c|c|c|c|}
\hline S/No & Sex & Age & Nutrient Agar & MacConkey Agar & $\begin{array}{l}\text { Mannitol } \\
\text { Salt Agar }\end{array}$ & S.S.A & $\begin{array}{c}\text { Eosin Methylene } \\
\text { Blue (E.M.B) }\end{array}$ & Organism \\
\hline S1 & $\mathrm{F}$ & 30 & $\begin{array}{l}\text { Large thick grayish } \\
\text { white, moist and } \\
\text { smooth }\end{array}$ & $\begin{array}{l}\text { Circular dark pink } \\
\text { colony }\end{array}$ & - & - & $\begin{array}{c}\text { Blue black colonies } \\
\text { with green metallic } \\
\text { sheen }\end{array}$ & E. coli \\
\hline S2 & $\mathrm{F}$ & 23 & $\begin{array}{l}\text { Large thick grayish } \\
\text { white, moist and } \\
\text { smooth }\end{array}$ & $\begin{array}{l}\text { Circular dark pink } \\
\text { colony }\end{array}$ & - & - & $\begin{array}{c}\text { Blue black colonies } \\
\text { with green metallic } \\
\text { sheen }\end{array}$ & E. coli \\
\hline S3 & $\mathrm{F}$ & 28 & $\begin{array}{l}\text { Large thick grayish } \\
\text { white, moist and } \\
\text { smooth }\end{array}$ & $\begin{array}{l}\text { Circular dark pink } \\
\text { colony }\end{array}$ & & & $\begin{array}{c}\text { Blue black colonies } \\
\text { with green metallic } \\
\text { sheen }\end{array}$ & E. coli \\
\hline S4 & M & 30 & $\begin{array}{c}\text { Milkish circular } \\
\text { colonies }\end{array}$ & circular & - & $\begin{array}{c}\text { Milkish circular } \\
\text { colonies }\end{array}$ & - & S. aureus \\
\hline S5 & $\mathrm{F}$ & 30 & $\begin{array}{c}\text { Milkish circular } \\
\text { colonies }\end{array}$ & circular & - & Yellowish colonies & - & S. aureus \\
\hline S6 & $\mathrm{F}$ & 31 & $\begin{array}{l}\text { Large thick grayish } \\
\text { white, moist and } \\
\text { smooth }\end{array}$ & $\begin{array}{l}\text { Circular dark pink } \\
\text { colony }\end{array}$ & - & - & $\begin{array}{c}\text { Blue black colonies } \\
\text { with green metallic } \\
\text { sheen }\end{array}$ & E. coli \\
\hline S7 & M & 34 & $\begin{array}{l}\text { Large thick grayish } \\
\text { white, moist and } \\
\text { smooth }\end{array}$ & $\begin{array}{l}\text { Circular dark pink } \\
\text { colony }\end{array}$ & - & - & $\begin{array}{c}\text { Blue black colonies } \\
\text { with green metallic } \\
\text { sheen }\end{array}$ & E. coli \\
\hline
\end{tabular}

Citation: Umeaku Chinyelu Nkiru., et al. "Isolation of Multi-Resistant Bacteria of Patients Suffering from Urinary Tract Infections in Owerri Metropolis, Imo State, Nigeria". Acta Scientific Microbiology 4.9 (2021): 03-16. 


\begin{tabular}{|c|c|c|c|c|c|c|c|c|}
\hline S8 & $\mathrm{F}$ & 26 & $\begin{array}{l}\text { Milkish circular } \\
\text { colonies }\end{array}$ & - & $\begin{array}{l}\text { Yellowish } \\
\text { colonies }\end{array}$ & - & & S. aureus \\
\hline S9 & $\mathrm{F}$ & 23 & _- & _- & _- & Dark blue colony & _- & Salmonella $s p$ \\
\hline S10 & $\mathrm{F}$ & 22 & $\begin{array}{l}\text { Milkish circular } \\
\text { colonies }\end{array}$ & - & $\begin{array}{l}\text { Yellowish } \\
\text { colonies }\end{array}$ & & - & S. aureus \\
\hline S11 & $\mathrm{F}$ & 20 & $\begin{array}{l}\text { Large thick grayish } \\
\text { white, moist and } \\
\text { smooth }\end{array}$ & $\begin{array}{l}\text { Circular dark pink } \\
\text { colony }\end{array}$ & - & - & $\begin{array}{c}\text { Blue black colonies } \\
\text { with green metallic } \\
\text { sheen }\end{array}$ & E. coli \\
\hline S12 & $\mathrm{F}$ & 22 & $\begin{array}{l}\text { Large thick grayish } \\
\text { white, moist and } \\
\text { smooth }\end{array}$ & $\begin{array}{l}\text { Circular dark pink } \\
\text { colony }\end{array}$ & - & - & $\begin{array}{l}\text { Blue black colonies } \\
\text { with green metallic } \\
\text { sheen }\end{array}$ & E. coli \\
\hline S13 & M & 25 & $\begin{array}{l}\text { Large thick grayish } \\
\text { white, moist and } \\
\text { smooth }\end{array}$ & $\begin{array}{l}\text { Circular dark pink } \\
\text { colony }\end{array}$ & - & - & $\begin{array}{l}\text { Blue black colonies } \\
\text { with green metallic } \\
\text { sheen }\end{array}$ & E. coli \\
\hline S14 & $\mathrm{F}$ & 26 & $\begin{array}{l}\text { Large thick grayish } \\
\text { white, moist and } \\
\text { smooth }\end{array}$ & $\begin{array}{l}\text { Circular dark pink } \\
\text { colony }\end{array}$ & - & - & $\begin{array}{l}\text { Blue black colonies } \\
\text { with green metallic } \\
\text { sheen }\end{array}$ & E. coli \\
\hline S15 & $\mathrm{F}$ & 32 & $\begin{array}{l}\text { Large thick grayish } \\
\text { white, moist and } \\
\text { smooth }\end{array}$ & $\begin{array}{l}\text { Circular dark pink } \\
\text { colony }\end{array}$ & - & - & $\begin{array}{l}\text { Blue black colonies } \\
\text { with green metallic } \\
\text { sheen }\end{array}$ & E. coli \\
\hline S16 & $\mathrm{F}$ & 28 & $\begin{array}{l}\text { Large thick grayish } \\
\text { white, moist and } \\
\text { smooth }\end{array}$ & $\begin{array}{l}\text { Circular dark pink } \\
\text { colony }\end{array}$ & - & - & $\begin{array}{l}\text { Blue black colonies } \\
\text { with green metallic } \\
\text { sheen }\end{array}$ & E. coli \\
\hline S17 & M & 35 & $\begin{array}{l}\text { Large thick grayish } \\
\text { white, moist and } \\
\text { smooth }\end{array}$ & $\begin{array}{l}\text { Circular dark pink } \\
\text { colony }\end{array}$ & - & - & $\begin{array}{l}\text { Blue black colonies } \\
\text { with green metallic } \\
\text { sheen }\end{array}$ & E. coli \\
\hline S18 & M & 30 & $\begin{array}{l}\text { Milkish circular } \\
\text { colonies }\end{array}$ & & $\begin{array}{c}\text { Yellowish } \\
\text { colonies }\end{array}$ & - & - & S. aureus \\
\hline S19 & $\mathrm{F}$ & 26 & $\begin{array}{l}\text { Large thick grayish } \\
\text { white, moist and } \\
\text { smooth }\end{array}$ & $\begin{array}{l}\text { Circular dark pink } \\
\text { colony }\end{array}$ & - & - & $\begin{array}{l}\text { Blue black colonies } \\
\text { with green metallic } \\
\text { sheen }\end{array}$ & E. coli \\
\hline S20 & $\mathrm{F}$ & 25 & $\begin{array}{l}\text { Large thick grayish } \\
\text { white, moist and } \\
\text { smooth }\end{array}$ & $\begin{array}{l}\text { Circular dark pink } \\
\text { colony }\end{array}$ & - & - & $\begin{array}{c}\text { Blue black colonies } \\
\text { with green metallic } \\
\text { sheen }\end{array}$ & E. coli \\
\hline S21 & $\mathrm{F}$ & 27 & $\begin{array}{c}\text { Circular greenish } \\
\text { colonies }\end{array}$ & $\begin{array}{l}\text { Bright circular pink } \\
\text { colonies }\end{array}$ & - & - & - & P. aeruginosa \\
\hline S22 & $\mathrm{F}$ & 21 & - & - & - & Dark blue colony & - & Salmoneelaspp \\
\hline S23 & $\mathrm{F}$ & 26 & $\begin{array}{c}\text { Milkish circular } \\
\text { colonies }\end{array}$ & - & $\begin{array}{l}\text { Yellowish } \\
\text { colonies }\end{array}$ & - & - & S. aureus \\
\hline S24 & M & 28 & $\begin{array}{l}\text { Milkish circular } \\
\text { colonies }\end{array}$ & - & $\begin{array}{l}\text { Yellowish } \\
\text { colonies }\end{array}$ & - & - & S. aureus \\
\hline S25 & $\mathrm{F}$ & 32 & $\begin{array}{l}\text { Large thick grayish } \\
\text { white, moist and } \\
\text { smooth }\end{array}$ & $\begin{array}{l}\text { Circular dark pink } \\
\text { colony }\end{array}$ & - & - & $\begin{array}{l}\text { Blue black colonies } \\
\text { with green metallic } \\
\text { sheen }\end{array}$ & E. coli \\
\hline
\end{tabular}




\begin{tabular}{|c|c|c|c|c|c|c|c|c|}
\hline S26 & $\mathrm{F}$ & 20 & $\begin{array}{l}\text { Large thick grayish } \\
\text { white, moist and } \\
\text { smooth }\end{array}$ & $\begin{array}{l}\text { Circular dark pink } \\
\text { colony }\end{array}$ & - & - & $\begin{array}{c}\text { Blue black colonies } \\
\text { with green metallic } \\
\text { sheen }\end{array}$ & E. coli \\
\hline S27 & $\mathrm{F}$ & 24 & $\begin{array}{c}\text { Large thick grayish } \\
\text { white, moist and } \\
\text { smooth }\end{array}$ & $\begin{array}{l}\text { Circular dark pink } \\
\text { colony }\end{array}$ & - & - & $\begin{array}{c}\text { Blue black colonies } \\
\text { with green metallic } \\
\text { sheen }\end{array}$ & E. coli \\
\hline $\mathrm{S} 28$ & $\mathrm{~F}$ & 26 & - & - & - & Dark blue colony & - & Salmoneelaspp \\
\hline S29 & $\mathrm{F}$ & 32 & $\begin{array}{l}\text { Extremely mucoid } \\
\text { and raised milkish } \\
\text { colonies }\end{array}$ & $\begin{array}{l}\text { Large dark pink } \\
\text { colonies }\end{array}$ & - & - & $\begin{array}{l}\text { Large mucoid pink } \\
\text { to purple colonies }\end{array}$ & Klebsiellaspp \\
\hline S30 & $\mathrm{F}$ & 40 & $\begin{array}{c}\text { Milkish circular } \\
\text { colonies }\end{array}$ & - & $\begin{array}{c}\text { Yellowish } \\
\text { colonies }\end{array}$ & - & - & S. aureus \\
\hline S31 & $\mathrm{F}$ & 38 & $\begin{array}{l}\text { Large thick grayish } \\
\text { white, moist and } \\
\text { smooth }\end{array}$ & $\begin{array}{l}\text { Circular dark pink } \\
\text { colony }\end{array}$ & - & - & $\begin{array}{c}\text { Blue black colonies } \\
\text { with green metallic } \\
\text { sheen }\end{array}$ & E. coli \\
\hline S32 & $\mathrm{F}$ & 21 & $\begin{array}{c}\text { Large thick grayish } \\
\text { white, moist and } \\
\text { smooth }\end{array}$ & $\begin{array}{c}\text { Circular dark pink } \\
\text { colonies }\end{array}$ & - & - & $\begin{array}{c}\text { Blue black colonies } \\
\text { with green metallic } \\
\text { sheen }\end{array}$ & E. coli \\
\hline S33 & $\mathrm{F}$ & 30 & $\begin{array}{l}\text { Circular greenish } \\
\text { colonies }\end{array}$ & $\begin{array}{l}\text { Bright circular pink } \\
\text { colonies }\end{array}$ & - & - & - & P.aeruginosa \\
\hline S34 & M & 29 & $\begin{array}{c}\text { Large thick grayish } \\
\text { white, moist and } \\
\text { smooth }\end{array}$ & $\begin{array}{l}\text { Circular dark pink } \\
\text { colonies }\end{array}$ & - & - & $\begin{array}{c}\text { Blue black colonies } \\
\text { with green metallic } \\
\text { sheen }\end{array}$ & E. coli \\
\hline S35 & $\mathrm{F}$ & 26 & $\begin{array}{l}\text { Milkish circular } \\
\text { colonies }\end{array}$ & - & $\begin{array}{c}\text { Yellowish } \\
\text { colonies }\end{array}$ & - & - & S. aureus \\
\hline S36 & $\mathrm{F}$ & 23 & $\begin{array}{c}\text { Extremely mucoid } \\
\text { and raised milkish } \\
\text { colonies }\end{array}$ & $\begin{array}{l}\text { Large dark pink } \\
\text { colonies }\end{array}$ & - & - & $\begin{array}{l}\text { Large mucoid pink } \\
\text { to purple colonies }\end{array}$ & Klebsiella spp \\
\hline S37 & $\mathrm{F}$ & 21 & - & - & - & Dark blue colony & - & Salmonella spp \\
\hline S38 & $\mathrm{F}$ & 24 & $\begin{array}{c}\text { Large thick grayish } \\
\text { white, moist and } \\
\text { smooth }\end{array}$ & $\begin{array}{l}\text { Circular dark pink } \\
\text { colonies }\end{array}$ & - & - & $\begin{array}{c}\text { Blue black colonies } \\
\text { with green metallic } \\
\text { sheen }\end{array}$ & E. coli \\
\hline S39 & $\mathrm{F}$ & 25 & $\begin{array}{l}\text { Large thick grayish } \\
\text { white, moist and } \\
\text { smooth }\end{array}$ & $\begin{array}{c}\text { Circular dark pink } \\
\text { colonies }\end{array}$ & - & - & $\begin{array}{c}\text { Blue black colonies } \\
\text { with green metallic } \\
\text { sheen }\end{array}$ & E. coli \\
\hline S40 & $\mathrm{F}$ & 28 & $\begin{array}{c}\text { Milkish circular } \\
\text { colonies }\end{array}$ & - & $\begin{array}{c}\text { Yellowish } \\
\text { colonies }\end{array}$ & - & - & S. aureus \\
\hline S41 & $\mathrm{F}$ & 28 & $\begin{array}{c}\text { Extremely mucoid } \\
\text { and raised milkish } \\
\text { colonies }\end{array}$ & $\begin{array}{l}\text { Large dark pink } \\
\text { colonies }\end{array}$ & - & - & $\begin{array}{l}\text { Large mucoid pink } \\
\text { to purple colonies }\end{array}$ & Klebsiella spp \\
\hline S42 & M & 31 & $\begin{array}{l}\text { Large thick grayish } \\
\text { white, moist and } \\
\text { smooth }\end{array}$ & $\begin{array}{c}\text { Circular dark pink } \\
\text { colonies }\end{array}$ & - & - & $\begin{array}{c}\text { Blue black colonies } \\
\text { with green metallic } \\
\text { sheen }\end{array}$ & E. coli \\
\hline S43 & M & 25 & $\begin{array}{l}\text { Milkish circular } \\
\text { colonies }\end{array}$ & - & \begin{tabular}{|c|} 
Yellowish \\
colonies
\end{tabular} & - & - & S. aureus \\
\hline
\end{tabular}




\begin{tabular}{|c|c|c|c|c|c|c|c|c|}
\hline S44 & $\mathrm{F}$ & 20 & $\begin{array}{c}\text { Large thick grayish } \\
\text { white, moist and } \\
\text { smooth }\end{array}$ & $\begin{array}{c}\text { Circular dark pink } \\
\text { colonies }\end{array}$ & - & - & $\begin{array}{c}\text { Blue black colonies } \\
\text { with green metallic } \\
\text { sheen }\end{array}$ & E. coli \\
\hline S45 & $\mathrm{F}$ & 28 & $\begin{array}{c}\text { Large thick grayish } \\
\text { white, moist and } \\
\text { smooth }\end{array}$ & $\begin{array}{c}\text { Circular dark pink } \\
\text { colonies }\end{array}$ & - & - & $\begin{array}{c}\text { Blue black colonies } \\
\text { with green metallic } \\
\text { sheen }\end{array}$ & E. coli \\
\hline S46 & M & 26 & $\begin{array}{c}\text { Large thick grayish } \\
\text { white, moist and } \\
\text { smooth }\end{array}$ & $\begin{array}{c}\text { Circular dark pink } \\
\text { colonies }\end{array}$ & - & - & $\begin{array}{c}\begin{array}{c}\text { Blue black colonies } \\
\text { with green metallic } \\
\text { sheen }\end{array} \\
\end{array}$ & E. coli \\
\hline S47 & $\mathrm{F}$ & 22 & $\begin{array}{c}\text { Milkish circular } \\
\text { colonies }\end{array}$ & - & $\begin{array}{c}\text { Yellowish } \\
\text { colonies }\end{array}$ & - & - & S. aureus \\
\hline S48 & $\mathrm{F}$ & 26 & $\begin{array}{l}\text { Large thick grayish } \\
\text { white, moist and } \\
\text { smooth }\end{array}$ & $\begin{array}{c}\text { Circular dark pink } \\
\text { colonies }\end{array}$ & - & - & $\begin{array}{c}\text { Blue black colonies } \\
\text { with green metallic } \\
\text { sheen }\end{array}$ & E. coli \\
\hline S49 & $\mathrm{F}$ & 28 & $\begin{array}{l}\text { Large thick grayish } \\
\text { white, moist and } \\
\text { smooth }\end{array}$ & $\begin{array}{c}\text { Circular dark pink } \\
\text { colonies }\end{array}$ & - & - & $\begin{array}{c}\text { Blue black colonies } \\
\text { with green metallic } \\
\text { sheen }\end{array}$ & E. coli \\
\hline S50 & M & 33 & $\begin{array}{l}\text { Milkish circular } \\
\text { colonies }\end{array}$ & - & \begin{tabular}{|c|} 
Yellowish \\
colonies
\end{tabular} & - & - & S. aureus \\
\hline
\end{tabular}

Table 1: Morphological appearance of bacteria on different selective media.

\begin{tabular}{|c|c|c|c|c|c|c|c|c|}
\hline & E. co & & & & Organism & & & \\
\hline & S. aur & & $\begin{array}{c}\text { Salmonella } \\
\text { spp }\end{array}$ & P. aeruginosa & Klebsiella spp & & & Total \\
\hline & & Count & 6 & 5 & 0 & 0 & 0 & 11 \\
\hline$c_{0}$ & Male & $\begin{array}{l}\text { \% within } \\
\text { Sex }\end{array}$ & $54.5 \%$ & $45.5 \%$ & $0.0 \%$ & $0.0 \%$ & $0.0 \%$ & $100.0 \%$ \\
\hline sex & & Count & 22 & 8 & 4 & 2 & 3 & 39 \\
\hline & Female & $\begin{array}{l}\text { \% within } \\
\text { Sex }\end{array}$ & $56.4 \%$ & $20.5 \%$ & $10.3 \%$ & $5.1 \%$ & $7.7 \%$ & $100.0 \%$ \\
\hline Tot: & & Count & 28 & 13 & 4 & 2 & 3 & 50 \\
\hline$\% \mathrm{n}$ & Sex & $56.0 \%$ & $26.0 \%$ & $8.0 \%$ & $4.0 \%$ & $6.0 \%$ & $100.0 \%$ & \\
\hline
\end{tabular}

Table 2: Cross-tabulation Analysis between Sex and type of Organisms.

The result of the cross-tabulation analysis presented in table 2 showed that $E$. coli was found in $54.5 \%$ males and $56.4 \%$ females have E. coli organism; $45.5 \%$ males and $20.5 \%$ females have $S$ aureus; $10.3 \%$ females have Salmonella spp while none of the males has Salmonella spp; 5.1\% females have P. aeruginosa while no male has the organism, and no male has the Klebsiella spp organism but was found present in $7.7 \%$ female.

Also, the result revealed that $E$. coli was present in $56 \%$ of the total respondents; $S$. aureus was present in $26.0 \%$ of the total re- 
Isolation of Multi-Resistant Bacteria of Patients Suffering from Urinary Tract Infections in Owerri Metropolis, Imo State, Nigeria

spondents; Salmonella sp was present in $8.0 \%$ of the total respon- $\quad$ Total number of urine samples $=50$

dents; $P$. aeruginosa was present in $4.0 \%$ of the total respondents, $\quad$ Total number of female samples $=39$ and Klebsiella spp was present in $6.0 \%$ of the total respondents.

\begin{tabular}{|c|c|c|c|c|c|c|c|c|c|c|c|}
\hline $\mathbf{S} / \mathbf{N}$ & Organism & SXT & $\mathbf{C H}$ & SP & CPX & $\mathbf{A M}$ & $\mathbf{A U}$ & CN & PEF & GFX & $\mathbf{S}$ \\
\hline S1 & E. coli & $\mathrm{R}$ & $\mathrm{R}$ & 11.0 & 18.0 & 5.0 & 21.0 & 7.0 & 11.0 & 18.0 & $\mathrm{R}$ \\
\hline S2 & E. coli & 8.0 & $\mathrm{R}$ & 13.0 & 15.0 & 10.0 & 18.0 & $\mathrm{R}$ & 18.0 & 22.0 & $\mathrm{R}$ \\
\hline S3 & E. coli & 13.0 & $\mathrm{R}$ & 17.0 & 10.0 & 8.0 & 13.0 & $\mathrm{R}$ & 13.0 & 11.08 & 8.0 \\
\hline S6 & E. coli & $\mathrm{R}$ & 6.0 & 20.0 & 16.0 & 7.0 & 11.0 & 5.0 & 9.0 & 14.0 & 3.0 \\
\hline S7 & E. coli & $\mathrm{R}$ & 10.0 & 8.0 & 2.0 & 13.0 & 7.0 & 2.0 & 5.0 & $\mathrm{R}$ & $\mathrm{R}$ \\
\hline S9 & Salmonella & $\mathrm{R}$ & $\mathrm{R}$ & 13.0 & 17.0 & 10.0 & 19.0 & $\mathrm{R}$ & 10.0 & 11.0 & 8.0 \\
\hline S 11 & E. coli & 5.0 & 2.0 & 18.0 & 7.0 & 13.0 & 18.0 & 3.0 & 11.0 & 18.0 & 4.0 \\
\hline S12 & E. coli & 13.0 & 5.0 & 23.0 & 17.0 & 11.0 & 19.0 & $\mathrm{R}$ & 17.0 & 21.0 & $\mathrm{R}$ \\
\hline S13 & E. coli & 19.0 & $\mathrm{R}$ & 15.0 & 13.5 & 8.5 & 13.0 & 19.0 & $\mathrm{R}$ & 18.0 & 2.0 \\
\hline S14 & E. coli & 7.0 & 13.0 & 19.5 & 11.0 & 6.5 & 18.0 & $\mathrm{R}$ & 18.0 & 14.5 & 7.5 \\
\hline S15 & E. coli & 13.0 & 17.0 & 13.0 & 13.0 & 11.0 & 17.0 & $\mathrm{R}$ & 13.0 & 11.0 & $\mathrm{R}$ \\
\hline S16 & E. coli & $\mathrm{R}$ & $\mathrm{R}$ & 10.0 & 6.0 & 8.0 & 8.0 & 3.0 & 11.0 & 6.0 & 6.0 \\
\hline S17 & E. coli & 3.0 & 8.0 & 11.0 & 19.0 & 7.0 & 18.0 & $\mathrm{R}$ & 16.0 & 14.0 & 3.0 \\
\hline S19 & E. coli & 8.0 & 10.0 & 14.0 & 11.0 & 17.0 & 13.0 & 8.0 & 15.0 & 13.0 & 6.0 \\
\hline S20 & E. coli & 10.0 & 13.0 & 8.0 & 13.0 & 6.0 & 9.0 & 3.5 & 9.0 & 12.0 & 10.0 \\
\hline S21 & P. aeruginosa & 8.0 & 11.0 & 13.0 & 8.0 & 17.0 & 17.0 & 1.0 & 21.0 & 9.0 & $\mathrm{R}$ \\
\hline S22 & Salmonella & 10.0 & 7.5 & 15.0 & 11.0 & 15.0 & 21.0 & 4.0 & 19.0 & 16.0 & $\mathrm{R}$ \\
\hline S25 & E. coli & $\mathrm{R}$ & $\mathrm{R}$ & 13.0 & 9.0 & 4.6 & 13.0 & $\mathrm{R}$ & 3.5 & $\mathrm{R}$ & $\mathrm{R}$ \\
\hline S26 & E. coli & $\mathrm{R}$ & 3.0 & 7.0 & 13.0 & 16.0 & 13.0 & 5.0 & 9.0 & 4.0 & $\mathrm{R}$ \\
\hline S27 & E. coli & 3.0 & $\mathrm{R}$ & 10.0 & 14.0 & 9.0 & 14.0 & $\mathrm{R}$ & 13.0 & $\mathrm{R}$ & $\mathrm{R}$ \\
\hline S28 & Salmonella & 5.0 & $\mathrm{R}$ & 13.0 & 10.0 & 11.0 & 10.0 & $\mathrm{R}$ & 11.0 & $\mathrm{R}$ & $\mathrm{R}$ \\
\hline S29 & Klebsiella & $\mathrm{R}$ & $\mathrm{R}$ & 8.0 & 5.0 & 13.0 & 11.0 & $\mathrm{R}$ & 8.0 & $\mathrm{R}$ & $\mathrm{R}$ \\
\hline S31 & E. coli & 8.0 & $\mathrm{R}$ & 9.0 & 11.0 & 13.0 & 8.0 & $\mathrm{R}$ & 5.0 & $\mathrm{R}$ & $\mathrm{R}$ \\
\hline S32 & E. coli & 3.0 & 5.0 & 3.0 & 7.0 & 7.5 & 5.0 & 3.0 & 8.0 & 3.0 & $\mathrm{R}$ \\
\hline S33 & P. aeruginosa & $\mathrm{R}$ & $\mathrm{R}$ & 7.0 & 4.0 & 3.6 & 8.0 & 2.0 & 10.0 & 6.0 & 3.0 \\
\hline S34 & E. coli & 10.0 & $\mathrm{R}$ & 5.0 & 8.0 & 10.0 & 11.0 & $\mathrm{R}$ & 5.0 & $\mathrm{R}$ & 5.0 \\
\hline S36 & Klebsiella & 8.0 & 10.0 & 9.5 & 5.6 & 9.0 & 11.0 & 4.0 & 8.0 & 4.0 & $\mathrm{R}$ \\
\hline S37 & Salmonella & 4.0 & 5.0 & 7.0 & 4.2 & 11.2 & 14.2 & 3.0 & 6.0 & 3.0 & $\mathrm{R}$ \\
\hline S38 & E. coli & 8.0 & $\mathrm{R}$ & 3.2 & 7.0 & 8.0 & 7.0 & $\mathrm{R}$ & 4.0 & $\mathrm{R}$ & 3.0 \\
\hline S39 & E. coli & $\mathrm{R}$ & 3.0 & 5.0 & 10.2 & 13.0 & 6.0 & 2.0 & 6.0 & 2.0 & $\mathrm{R}$ \\
\hline S41 & Klebsiella & 3.0 & $\mathrm{R}$ & 7.0 & 7.2 & 8.0 & 10.0 & $\mathrm{R}$ & 3.0 & 3.0 & $\mathrm{R}$ \\
\hline S42 & E. coli & 5.0 & $\mathrm{R}$ & 3.0 & 6.0 & 11.0 & 9.5 & 1.0 & 6.0 & 8.0 & 3.2 \\
\hline S44 & E. coli & 7.0 & 2.0 & 8.2 & 3.6 & 9.0 & 7.0 & $\mathrm{R}$ & 4.6 & 6.6 & 6.0 \\
\hline S45 & E. coli & $\mathrm{R}$ & 4.2 & 6.0 & 2.0 & 6.0 & 6.2 & $\mathrm{R}$ & 7.0 & $\mathrm{R}$ & 7.2 \\
\hline
\end{tabular}




\begin{tabular}{|l|c|c|c|c|c|c|c|c|c|c|c|}
\hline S46 & E. coli & 2.0 & 6.6 & 8.0 & 10.2 & 11.0 & 8.0 & $\mathrm{R}$ & 5.0 & $\mathrm{R}$ & 3.0 \\
\hline S48 & E. coli & 6.0 & $\mathrm{R}$ & 3.0 & 8.0 & 13.0 & 5.2 & 7.0 & 8.0 & 5.0 & $\mathrm{R}$ \\
\hline S49 & E. coli & $\mathrm{R}$ & 5.0 & 4.5 & 5.0 & 8.0 & 10.0 & 8.2 & 10.0 & 3.0 & 2.0 \\
\hline
\end{tabular}

Table 3: Zone of inhibition of isolates on antibiotics pregnates discs.

Key

$\mathrm{R}=$ Resistance

SXT $=$ Septrin 30ug

$\mathrm{CH}=$ Chloramphenical 30ug

$\mathrm{SP}=$ Sparfloxacin 10ug

CPX= Ciprofloxacin 30ug

$\mathrm{AU}=$ Augmentin 10ug

$\mathrm{AM}=$ Amoxacillin 30ug

$\mathrm{CN}=$ Gentamycin 30ug

$\mathrm{PEF}=$ Pefloxacin 30ug

GFX= Tarivid 10ug

$\mathrm{S}=$ Streptomycin 30ug.

\begin{tabular}{|l|c|c|c|c|c|c|c|c|c|c|c|}
\hline S/n & Organism & PEF & CN & APX & Z & AM & R & CPX & S & SXT & E \\
\hline S4 & S. aureus & 25.0 & 10.0 & 12.0 & 18.0 & 20.0 & 23.0 & 19.0 & $\mathrm{R}$ & $\mathrm{R}$ & 5.0 \\
\hline S5 & S. aureus & 10.0 & 15.0 & 9.0 & 10.0 & $\mathrm{R}$ & 10.0 & 7.0 & 5.0 & $\mathrm{R}$ & $\mathrm{R}$ \\
\hline S8 & S. aureus & 19.0 & 13.0 & 14.0 & 17.0 & 5.0 & 13.0 & 15.0 & $\mathrm{R}$ & 5.0 & 10.0 \\
\hline S10 & S. aureus & 13.0 & 20.0 & 8.0 & 15.0 & 10.0 & 17.0 & 18.0 & 13.0 & 11.0 & $\mathrm{R}$ \\
\hline S23 & S. aureus & 7.0 & 13.5 & 11.5 & 9.0 & 14.0 & 13.0 & 19.5 & 11.0 & $\mathrm{R}$ & 5.0 \\
\hline S24 & S. aureus & 13.0 & 8.0 & 9.0 & 13.0 & 7.0 & 11.0 & 15.5 & 8.0 & 9.0 & 3.0 \\
\hline S30 & S. aureus & 19.0 & 15.2 & 14.8 & 14.0 & 7.5 & 17.0 & 13.5 & 14.0 & 10.5 & $\mathrm{R}$ \\
\hline S35 & S. aureus & 13.0 & 10.0 & 12.0 & 11.0 & $\mathrm{R}$ & 13.0 & 9.5 & $\mathrm{R}$ & 130 & 3.5 \\
\hline S40 & S. aureus & 20.0 & 14.0 & 11.0 & 16.0 & 6.0 & 20.0 & 17.0 & 9.0 & 11.0 & 2.5 \\
\hline S42 & S. aureus & 13.0 & 10.0 & $\mathrm{R}$ & 11.0 & $\mathrm{R}$ & 18.0 & 13.0 & 8.0 & 10.0 & $\mathrm{R}$ \\
\hline S47 & S. aureus & 10.5 & 8.0 & 6.5 & 13.0 & $\mathrm{R}$ & 9.0 & 5.0 & 13.0 & 5.0 & $\mathrm{R}$ \\
\hline S50 & S. aureus & 10.6 & 6.6 & $\mathrm{R}$ & 14.0 & 3.0 & 10.6 & 7.0 & 4.6 & 8.0 & 2.0 \\
\hline
\end{tabular}

Table 4: Zone of inhibition of isolates on antibiotic impregnated discs.

Key:

$\mathrm{R}=$ Resistance

$\mathrm{PEF}=$ Pefloxacin $10 \mathrm{ug}$

$\mathrm{CN}=$ Gentamycin $10 \mathrm{ug}$

APX= Ampiclox 30ug

$\mathrm{Z}=$ Zinnacef $20 \mathrm{ug}$

$\mathrm{AM}=$ Amoxacillin 30ug

$\mathrm{R}=$ Rocephin $25 \mathrm{ug}$

CPX= Ciprofloxacin 10ug

$\mathrm{S}=$ Streptomycin $30 \mathrm{ug}$

SXT= Septrin 30ug

$\mathrm{E}=$ Erythromycin 10ug.

Citation: Umeaku Chinyelu Nkiru., et al. "Isolation of Multi-Resistant Bacteria of Patients Suffering from Urinary Tract Infections in Owerri Metropolis, Imo State, Nigeria". Acta Scientific Microbiology 4.9 (2021): 03-16. 
Escherichia coil $=22$

Staphylococcus aureus $=8$

Salmonella spp $=4$

Klebsiellaspp $=3$

Pseudomonaaeruginosa $=2$

Total number of male samples $=11$

Staphylococcus aureus $=5 ;$ Escherichia coli $=6$

Total number of isolates

Escherichia coli $=28$

Staphylococcus aureus $=13$

Salmonella $s p p=4$

Klebsiella $s p p=3$

Pseudomonas aeruginosa $=2$

Frequency occurrence of bacteria isolate

Escherichia coli $=\underline{28 \times 100}=56 \%$ 50

Staphylococcus aureus $=\underline{13 \mathrm{X} 100}=26 \%$

50

Salmonella $\operatorname{spp}=\underline{4 \mathrm{X} 100}=8 \%$

50

Klebsiella $s p p=\underline{3 \times 100}=6 \%$

50

Pseudomonas aeruginosa $=\underline{2 \times 100}=4 \%$

\section{Statistical data analysis}

Statistical analysis of all the data will be done using statistical package for social sciences (SPSS) version 20. The statistical tool used in the study includes percentage distribution, Chi-square test, Spearman Correlation test and One-way Analysis of Variance.

\section{Discussion}

The significant rise in urinary tract infection (UTI) among the adult as carried out in this dissertation is as a result of antimicrobi-

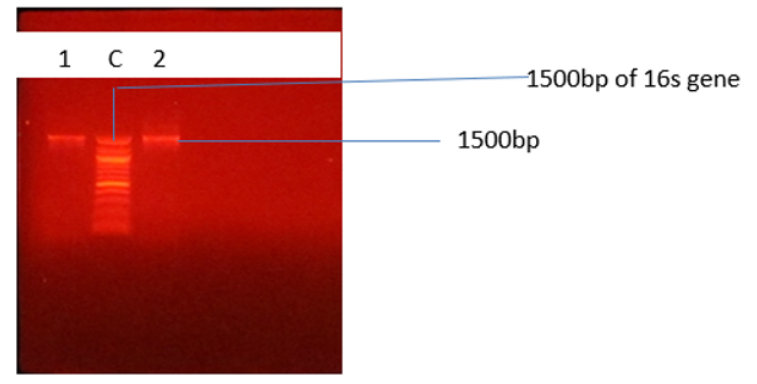

Plate 1: Agarose gel electrophoresis of 16SrRNA gene of bacteria isolates. Lane 1 and 2 represent 16SrRNA at $1500 \mathrm{bp}$. Lane $\mathrm{C}$ represents the $100 \mathrm{bp}$ Molecular ladder.

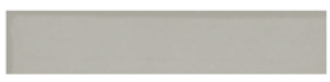

$1 \mathrm{M} 2$

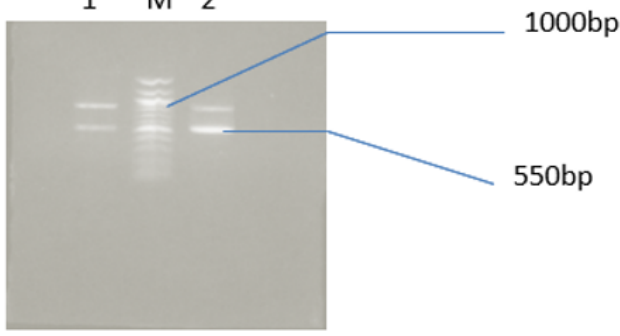

Plate 2: Agarose gel electrophoresis of CTX-M gene of some selected bacteria isolates. Lane 1 and 2 represents the CTX-M gene bands (550bp). Lane M represents the $100 \mathrm{bp}$ Molecular ladder of $1500 \mathrm{bp}$.

al resistance developed by these bacteria, Escherichia coli, Staphylococcus aureus, Salmonella spp, Shigella spp, and Klebsiella spp and this is in line with the report of [2].

Table 1 show that $54.4 \%$ of $E$. coli was isolated from male urine samples and $56.4 \%$ was isolated from female urine samples and this in line with the report of [5] whose work revealed that $63.3 \%$ of $E$. coli was isolated from female urine sample and $42.5 \%$ from male urine sample, hence, consolidating the result obtained from table 1. 


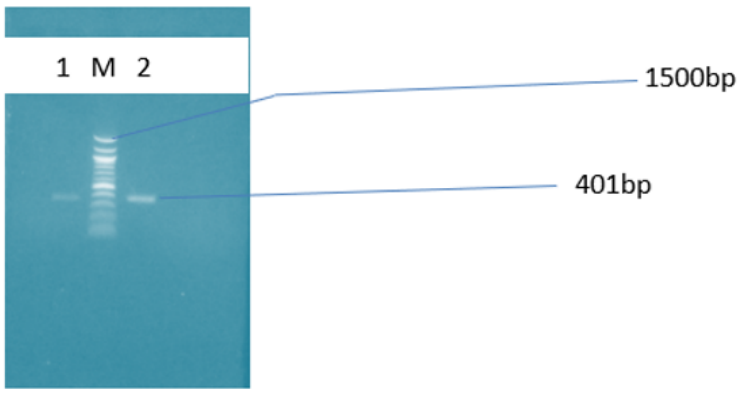

Plate 3: Showing Agarose gel electrophoresis of BlaTEM gene of some selected bacteria isolates. Lane 1 and 2 represents the SHV gene bands (401bp). Lane M represents the $100 \mathrm{bp}$ Molecular ladder of $1500 \mathrm{bp}$.

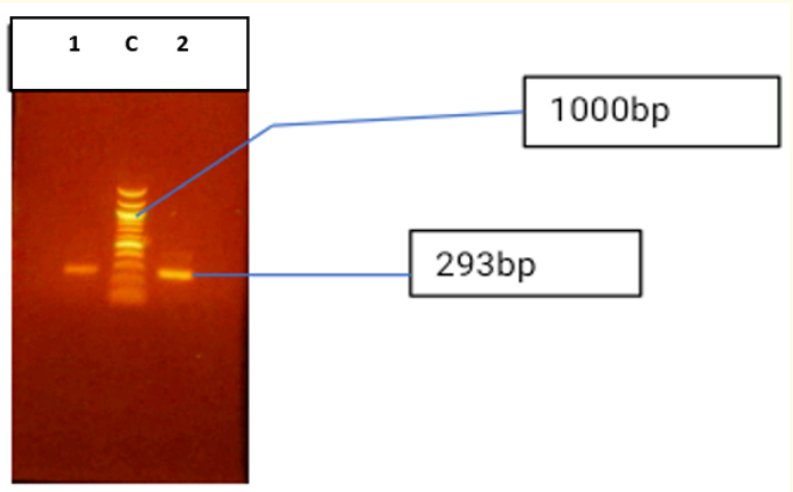

Plate 4: Agarose gel electrophoresis of SHV gene of some selected isolates. Lane 1 and 2 represents the SHV gene band (293bp). Lane C represents the $100 \mathrm{bp}$ molecular ladder of $1500 \mathrm{bp}$.

More so [6], had a high value of Klebsiella spp of 37\% isolated from urine sample of female cultured as compared with $7.7 \%$ of klebsiella spp isolated from female urine cultured as reported in table 1, proving that a lower rate of Klebsiella spp and Staphylococcus aureus was $26 \%$ when compared to [6] report which was $68.8 \%$.

In table 3, E. coli was mostly resistance to Septrin, Chloramphenicol, Gentamycin, Streptomycin and Taravid whereas Klebsi- ella spp and Salmonella spp were resistant to Gentamycin, Streptomycin, Amoxacillin as compared to [6], whose report shows that $E$. coli was mostly resistant to Amikam rather than mentioned drugs, which is contradicting but does was in correspondence with [13] report. Table 4 show the antibiotics that are resistant to Staphylococcus aureus to include; APX, AM, S, SXT and E.

The presence of CTX-M plasmid resistance in Escherichia coli, and Salmonella spp make them to be resistance determinants against most antimicrobial agent and this is in accordance with the report of [14] on CTX-M plasmid resistance gene of Escherichia coli and among other plasmid resistance gene seen in plate 1,3 and 4 respectively.

\section{Conclusion}

Some of the bacteria isolated and identified from the urinary tract infection are of public health importance, thus, when they develope resistance to antibiotics continue to be considered as a major cause of persistent urinary tract infection which could result to waist pain, incomplete menstrual cycle and eventual infertility occur. Therefore, this calls for regular surveillance and improved antibiotic stewardship.

\section{Recommendation}

- National Agency for food and Drug Administration (NAFDAC) and National Drug Law Enforcement Agency (NDLEA), should set up a local body nationwide to monitor the usage of Antibiotics especially when it involves in the treatment of Urinary tract infection in order health hazard as regards to the rate of resistance caused by the said organisms.

- Pharmacy and other Patients medical shops should always insist on seen the sensitivity of the patient laboratory result before carrying out any treatment.

- Urinary tract infection should not be treated with a thorough investigation and if approved should administer a normal and complete dose without interruption as this may lead to drug resistance by the organisms.

- There exist need to educate people to avoid drug abuse especially antibiotics at it may be detrimental to their health.

- Adequate measurement and proper hygiene should be employed by individual living in public and private facilities.

- Public health educative program should be of necessity to enlighten the general public about health implications of consuming drugs without proper or adequate check-up. 


\section{Bibliography}

1. W.H.O. "The soil as a source of micro-organisms antagonistic to disease-producing bacteria". Journal of Bacteriology 40 (2014): 581-600.

2. Anejo-okopi J A., et al. "Bacterial and antibiotic susceptibility pattern of urinary tract infection isolated from asymptomatic and symptomatic diabetic patients attending tertiary hospital in Jos, Nigeria". Trends in Medicine 17 (2017): 1-5.

3. Ngwu MI., et al. "Susceptibility pattern of a clinical isolate of Staphylococcus aureus to the combined activity of a herbal preparation of Azardirachta indica and some antibiotics". International Journal of Health Research 23 (2009): 279-286.

4. Yazdanpanah L., et al. "Literature review on the management of Diabetic Foot Ulcer". World Journal of Diabetes 156.1 (2015): 37-43.

5. Peterson E and Kaur P. "Antibiotic resistance mechanisms in bacteria: Relationship between resistance determinants of antibiotic producers, environmental bacteria and clinical pathogens". Frontiers in Microbiology (2019).

6. Bernabé KJ., et al. "Antimicrobial resistance in West Africa: a systematic review and meta-analysis". International Journal of Antimicrobial Agents 50 (2017): 629-639.

7. Iregbu KC and Nwajiobi-princewill P. "Urinary trait infections in a tertiary hospital Abuja, Nigeria". African Journal of Clinical and Experimental Microbiology 14.3 (2017): 169-173.

8. Lee D S., et al. "Community-Acquired Urinary Tract Infection by Escherichia coli in the Era of Antibiotic Resistance". BioMed Research International 5 (2018): 1-15.

9. Dada-Adegbola H O and Muili K A. "Antibiotic susceptibility pattern of urinary tract pathogens in Ibadan, Nigeria". African Journal of Medical Science 39.3 (2018): 173-179.

10. Clinical and Laboratory Standards Institute (CLSI). Performance standards for antimicrobial disk susceptibility tests; 12th ed. informational supplement (M02-A12). Wayne, PA, Clinical and Laboratory Standards Institute (2017).

11. Barber A E., et al. "Urinary Tract Infections: Current and Emerging Management Strategies". Clinical Infectious Diseases 57.5 (2018): 719-724.
12. Elsayed A., et al. "Molecular Characterization of Multidrug Resistant Clinical Escherichia coli Isolates". American Journal of Biochemistry and Molecular Biology 6 (2016): 72-83.

13. Concia E., et al. "Clinical evaluation of guidelines and therapeutic approaches in multidrug-resistant urinary tract infections". Journal of Chemotherapy 29.1 (2017): 19-28.

14. Carattoli A. "Plasmids and the spread of resistance". International Journal of Medical Microbiology 303.6-7 (2017): 298-304.

\section{Volume 4 Issue 9 September 2021 (C) All rights are reserved by Umeaku Chinyelu Nkiru., et al.}

